of friction, and had got hold of an abiurd idea that the value; of the various so-called imponderables could be expressed in quantitative terms, the one of the other. Fortunately for the credit of the Royal Society, someone $m$ rre far-seeing than these critics, expressed the opinion that the Council had batter take care what it was about, because if they acted on these ideas they might find that they, the highest scientific tribunal in the country, had refused to publish the most imporiant scientific discovery of the century, ant one which had already been received with acclamation by all Continental scientific authorities. And so the celebrated paper on the mechanical equivalent of heat was printed, seven years after its first announcement, in the Philosophical Transactions for 1850. But while this, with its immediate relations, was Joule's magnum opus, other portion: of his work were of scarcely less importance, and to one only of these did he (Sir Henry) wish f.or a moment to revert, as it touched on a fundamental principle in the science of chemistry, and was therefore specially interesting to himself, whilst it served to show the wide area which Joule's researches covered. On January 24, I843, Joule read a paper before the Literary and Philosophical Society in their rooms in George Street, hallowed by the memory of Dalton, entitled, "On the Heat evolved during the Electrolysis of Water." The results of this apparently trivial research were of the highest importance, as establishing the heat equivalence of chemical action. Dulong, in France, had alraady determined the amount of heat evolved during combustion, but he did not compare this with the heat evolved by the same combustion in the battery or elsewhere, and Joule's discovery, described in the above papers, was, that the heat which disappears during separation of the chemical elements was equal to that which made its appearance during their cumbination, on the principle that action and reaction were equal and opposite. And this was the discovery which established the law proving that che nical action was due to the clashing of the atoms, and that the same laws applied to those atom; singly as they did to the.n when taken in the aggregate, thus showing that chemistry was a tranch of molecular physics. He trusted he had given good grounds for the acceptance by that $m$ zeting of the resolution he moved. He would humbly suggest that $n$ thing short of a similar memorial to that erected to Dulton ought to be raised in Manchester in recognition of the labours of Joule. They had statues of Coblen, of Dalton, and of good Bishop Fraser ; they would soon have one of Bright. Let them not place Joale in any less conspicuous position, for his work was as glorious a; any of theirs. Let us have a marble statue as a companion to that beautiful one of Dalton, by Chantrey, in our Town Hall, and let us have a replica of it in bronze to place on our Infirmary flags, so that all who passed for generations might say, "That is the statue of our great Manchester man of science, James Prescott Joule, who did work in our mid it not less important than that of his master, John Dalton, whose statue is hard by; both men were honoured by their contemporaries, and are even more honoured by us who follow them."

Prof. Osborne Reynolds, in supporting the motion, expressed regret that they had not present with them Sir William Thomson, who fought the battle with Dr. Joule. Sir Willian had written a letter, in the course of which he said: "Manchester is certainly, of all cities in the world, to be envied the honour of being able to erect a monument to Joule as one of its own citizens." Professor Reynolds also made a statement as to the action which had been taken by the Manchester Literary and Philosophical Society, with whom the proposal for a memorial of 1)r. Joule originated.

On being put to the meeting, the motion was unanimously adopted.

Mr. Alderman W. H. Bailey moved the appointment of the following Committee to raise, by public subscription, a sufficient sum to carry the above resolution into effect, viz. :-Chairmanthe Mayor of Manchester; Treasurer-Oliver Heywood; Thomas .Ashton; the Ven. Archdeacon Anson; Sir William Cunliffe Brooks, Bart., M.P. ; Alderman W. H. Bailey; Rev. St. Vincent Beechey; C. H. Bayley; Dr. James Bottomley; William Brockbank; J. H. Buxton : Rev. L. C. Casartelli ; Councillor George Clay; R. S. Dale; Prof. W. Bayd Dawkins;:Mr. Thomas Diggles; Samuel Dixon, President of the M inchester Society of Engineers; F. J. Faraday, H.n. Serret iry of the Munchester Literary and Pnilosophical Society Lavington E. Fletcher; R. F. Gwyther, Hon. Secretary of the Minchester Literary and Philosophical Society; Samzel
Gratrix; Principal J. G. Greenwood; William Grimshaw ; Charles J. Galloway; Sir W. H. Houldsworth, Bart., M. P. ; T C. Horsfall ; Dr. Charles John Hall ; Thomas Harker ; Henry H. Howorth, M.P.; William W. Hulse ; Henry P. Holt; Isaac Hoyle, M.P. ; Dr. Edward Hopkinson; Canon Hicks; James Jardine, High Sheriff of Cheshire; W. H. Johnson; Thomas Kay; George King; Thomas Kay; Horace Lamb; Sir Joseph C. Lee; Ivan Levinstein ; J. W. Maclure, M.P. Councillor J. D. Milne; James Cosmo Melvill; Councillor Alexander M'DougalI, Jun. ; Robert Montgomery; Dr. Morgan ; William Mather, M.P.; Ludwig Mond (V.P. Chem. Soc.); Prof. J. E. C. Munro; Francis Nicholson; Councillor Charles O'Neill ; Henry D. Pochin; W. O. Pooley ; Sir H. E. Roscoe, M.P., ; Dr. Ransome; Prof. Osborne Reynolds ; Henry Slatter; Dr. Schunck ; Prof. Schuster; Councillor Dr. Henry Simpson; Colonel Thomas Sowler; William Thomson; Alderman Joseph Thompson; Councillor S. Chesters-Thompson; E. Leader Williams; Professor A. W. Ward ; Thomas Worthington; Rev. Canon Charles W. Woodhouse. Convener of first meeting, Prof. Osborne Reynolds. In his remarks in support of the motion, Mr. Bailey said that speaking as an exPresident of the Manchester Society of Engineers he could testify that, however slow many people might have been to acknowledge Dr. Joule's work, the Society of Engineers had never forgotten Dr. Joule's labours and the benefit which those labours had conferred on the engineers of this country and on the industries of the world generally.

The motion was seconded by Colonel T. Sowler and unanimously adopted.

A vote of thanks to the Mayor for presiding and for the use of his parlour, accorded on the motion of Prof. Ward, seconded by Mr. C. Bailey, brought the proceedings to a close.

\section{HOW PLANTS MAINTAIN THEMSELVES IN THE STRUGGLE FOR EXISTENCE. ${ }^{1}$}

RDINARY English scenery, so full of quiet and so suggest. ive of repose that one may not realily discover signs of a struggle for existence. In tropical scenery these signs are so clear that they have been recognized again and again by every thinking natu ralist who has ever visited tropical regions.

Any comprehensive view of the phenomenon of life upon the globe clearly points to the one conclusion that all Nature is in a perpetual state of desperate warfare, and the keynote of this address must be : the utter remorselessness of Nature, the care for self; the absolute disregard for others. In all cases the weakest goes to the wall.

\section{Evidences of Struggle for Existen:e in the Plant World.}

Ficus parasitica. Seed dropped by hird germinates on fork of some tree, e.g. the jack fruit (Artocarpus inteorifolia); sends long root into soil ; gradually spreads itself over, and suffocates the unfortunate foster-mother.

Heracleum giganteum. Allowed to seed itself freely. On June I, 1839,573 seediings had germinated; on August 19, I0 5 remained, the missing ones having been killed by the more vigorous survivors.

Bertholletia excelsa. Fifteen to twenty-four Brazil nuts are contained in each fruit, the fruit being indehiscent. All seeds germinate at once. The most vigorous gets first through a small hole at the top to the open air, and strangles and feeds upon all the rest.

$$
\text { What Plants strugryle for. }
$$

Plants struggle for two main objects-viz. their own nutrition, and the reproduction of their species by means of offspring, which they leave behind them, and for which they make adequate provision. The two master functions, nutrition and re production, often stand out clearly marked the one from the other-e.g. in the Talipot palm (Corypha umbraculifera), where the period of leaf-bearing is succeeded by the period of fruiting, the latter being accompanied by the final death of the whole plant.

\section{I. -Nutrition.}

\section{Protective Adaptations associnted with the mainly Nutritive} Organs.

(I) Mechanical contrivances. Large forest trees (often 200 feet high) have buttressed trunks, e.g. (anarium commune.

${ }^{r}$ Abstract furnished by the Author, Prof. Walter Gardiner, of a lecture delivered at the Newcastle meeting of the British Ass cciation. 
(2) Large leaves in palms (often 14 feet long), tied in at the leaf-hase, e.g. Didymospermum distichum.

(3) Young buds of many tropical trees hang vertically downwards, so as to expose the least surface to sun, e.g. Amherstia nobilis.

(4) Prickles and spines developed, e.g. immense leaf of Victoria regia is rotected from fish, \&c., which, in rising from below, might rupture the leaf-tissue.

(5) Patrols of ants attracted. Ants provided with home, honey, and food, e.g. Acacia spharocepriala. Similarly, Ifomea faniculata attracts ants by racemose glands supplied with definite ducts, two of which are present in each leaf, at junction of blade and stalk.

(6) During the unfolding and growth of the bud, special mechanisms exist. Thus, water-glands occur at the apex of each leaf-tooth (Saxifraga crustata), which provide for the escape of the superabundant water sucked up by the root : otherwise the delicate leaf-tissue might be ruptured. In fully developed leaves, on a cold night, drops may be seen escaping from the teeth, $e \cdot g$. balsam (Impatiens Balsamina).

Other glands are also found which secrete mucilage or resin, and so protect the young structures from the effects of excessive drought, e.g. ferns (Blechnum Braziliense) and other plants (Clusia sp. and Coprosmasp.).

\section{II. - REPKODUCTION.}

The importance of this process is sufficiently obvious from the enormous expenditure of material and energy plants lavish upon it. Hodgsoniza heterocli'a, an extraordinary Indian climber, with its complicated structure and great beauty, opens for one night only, and shrivels up and falls off the next day. Amorphofhallus Titanum, with its huge inflorescence (the largest in the world), although it takes months to develop, opens only on one night, and then only for a few hours.

$$
\text { a.-Flowers. }
$$

(I) Contrivances to insure fertilization. Masdevaliia muscosa (an orchid) has a sensitive labellum. An insect alighting on it and touching a certain part, is shot into the flower and held a prisoner for some time.

(2) Frotection by means of sticky hairs. Cuphea si'enoides is protected from the attacks of inse ts by very numerous hairs secreting a gum resin. Many insects are caught, and as many as 7280 may be counted on one plant.

(3) Plant protected by ants, but flower fertilized by some other insect. Plumbago rosea has nectaries on the leaves and flowerbracts which attract ants, but the ants are prevented by sticky bairs on the calyx from obtaining access to the honey in the flower.

$$
\text { B.- Seeds and Fruits. }
$$

Some plants depend upon the enormous quantity of seeds produced-e.g. the wild carrot (Daucus carota), which, moreover, sows its seeds by instalments and at different times. Others-... e.g. Viandzeia subterranea-sacrifice the advantages obtained from a wide dispersal, and depend upon the formation of a few seeds suitably placed in the soil. This plant, in fact, has a mechanism for itself, sowing its own seeds beneath the soil.

For purposes of distribution, Uncinia brevicantis (a sedge) has its fruit provided with small hooks. Smali birds, unable to pull out the fruits, are occasionally caught and killed in Jamaica. The fruits of Stifa penriata, a grass, bore their way into the ground; and another specie, Stipa sparlea, is even liable to bore its way into the bodies of sheep which are so unfortunate as to come in its neighbourhood (prairies west of Red River Colony).

Contrivances for assisting plants to maintain themselves in the struggle for existence are by no means limited to the higher plants. They exist also in the Fungi and the Algæ, even in the smallest and most microscopic of them. Examples --

I. Fungi.-Clathrus triscapus, a Queensland fangus, has an orange-red colour, and the spores smell strongly and are embedded in a sweet mucilage. Col, ur, scent, ard sweetness are the usual advertisements used by the higher plants in connection with pollen dispersion.

Erys phe Alni. The mildew of the alder has wonderfully hooked fruits, which are posibly carried about by tiny Acari, $\& c$. Spores are shot out with some force from the mycelial filaments of the fungus, which attacks and kills flies, Empusa musca. The ergot Claziceps purpurea, at the time of spore- formation, secretes a sugary nectar, so that flies are altracted, and eat and disseminate the spores, just as birds do stone fruits. The spores of Sclerotina Vaccinii have an almond smell; are gathered by bees with the pollen, and, being placed on the -tigma of healthy flowers, infect the ovary and prevent the formation of seed. In the race between the pollen-grain tube (the rightful owner) and the fungus-spore mycelial-tube, the fungus always wins, and soon spreads itself throughout the tissue of the entire ovary, producing more srores for the bees to gather in mistake again.

II. Alga.-The resting-spores of Desmids-microscopically small green $A$ lgx - are frequently covered by a spiny siliceous coat. These probably prevent them from being eaten by $A m a b c$, Khizopods, \&c. The protoplasm of certain cells of CEdosoniunt ciliatum (a fresh-water filamentous Alga) are in the habit of escaping from the cell-wall and beginning life anew. This production of the so-called szuarm-sfore is probably not wholly unconnected with the existence of unfavourable conditions, e.g. Bacteria on the cell-wall, deposits of lime on the cell-wall, \&c.

Mesocarpus sp., another filamentous Alga, carefully protects its chlorophyll plate from too bright light by turning it so that it shall receive the proper amount only. Should external conditions be exceptionally unfavourable, the protoplasm of the various cells powerfully contracts, and the filament resolves itself into its vaisous constituent units, which sink to the bottom of the river or pond, and there divide up and start afresh.

\section{Spccial Puinls zerorthy of notice.}

(1) Various adaptations by memhers of the same order, e.s. the Cucurbitacere (Cucumber family), in the matter of seed distribution.

In Schizocarpum filiforme the seeds escape through a number of slits in the wall of the fruit.

In Ecbalizm elatine the seeds are violently and explosively shot out in consequence of the sudden rupture of the fruit stalk. Sechizm edule is indehiscent and contains only one seed.

Zanonia macrocarpa dehisces at the apex by means of valves, and lets out winged seeds of extraordinary beauty, which, aided by the wind, can cover very appreciable distances.

(2) Various adaptations by members of the same genus, e.g. Clerodendrons.

Clirodendron Koemferi attracts ants by small glands on the leaf and calyx.

Clerodendron fistulosum does the same, but also provides a home for the ants in its hollow stem.

Clerodendron cephalanthum climbs by means of peculiarly modified leaf stalks; has a multiplicity of buds on the axil of each leaf (instead of the usual one) and also possesses glands upon its leaves.

Such families as this may well be regarded as accomplished, but at the same time their various contrivances are simply so many marks of a cruel and fierce fight.

(3) Protective contrivances associated with new annual groweth and sermination.

Dioscorea, sp. noz., at each new period of growth produces at first inconspicuous shoots with small leaves which are peculiarly modified into climbing organs. When well established and in the possession of a proper support large green leaves appear.

Hodgsonia heteroclita.-Here again the shoot on its first appearance is dark purple and inconspicuous, with the leaves r resent merely as scales. It can then scarcely be seen in the tropical forest. Moreover it is a lateral shoot and not the main terminal shoot which it first protrudes above ground. A second lateral and the main terminal are held in reserve against possible accident. When it has reached a certain height, it produces the normal large leaves.

(4) The accumulation of pro'ective contrivances in the same individual.

Bizmenbachia Hieronymi.-The flower is at first upright and is fertilized in that position. As the fruit develops, the flowerstalk elongates and the fruit is gradually and gently placed upon the ground. Until quite ripe, it is protected by stinging hairs. Later on, these wither, and the fruit is distributed by means of a second series of grapple hairs, which cling firmly to any passing animal.

Strophanthus hispidus. - Fruit, when ripe, opens, and lets ont a number of magnificent plumed seeds, which are carried by the wind. The hairs forming the plume are sensitive to moisture and dryness, and are each capable of moving through an arc of $180^{\circ}$. The hairs spread out in dry weather, so that the seed 
may be carried by the wind. They close up tightly when the rains come, so that they may not interfere with the placing of the seed close to the ground and its consequent germination. Sooner or later they break from the seed.

(5) Particular adaptations contrived for particular classes of insects, $\mathcal{S}^{\circ} \mathrm{c}$.

Ants are caught and killed at Kew by flowers of Eria stricta (an orchid). The ants are too large for the flower, but they visit it for the sake of the honey and get caught in the mucilage. Thus both flower and ant suffer.

(6) The mutual adaptation of hlants and animals.

In some instances animals and plants appear to strive with each other, and, as the one develops a particular protective contrivance, the other likewise adopts some plan to counteract it and annul its efficiency: thus the canari nut (the fruit of Canarizm commune) develops a hard shell which protects it from most enemies, but the black cockatoo (Microglossus aterrimus) reciprocates by developing a wonderfully strong beak, which appears indeed to be developed with a special view to the canari nut. Insects also often imitate parts of plants for their own benefit, e.g. leaf insects.

\section{UNIVERSITY AND EDUCATIONAL INTELLIGENCE.}

CAMBRIDGE. - The Senate has formally thanked Prof. Sedgwick for his munificent gift towards the new buildings for physiology, and the Museums and Lecture Rooms Syndicate has been authorized to contract for the buildings to be immediately begun.

The following stipends have been augmented: Dr. Gaskell, F.R.S., University Lecturer in Physiology, from $£ 50$ to $£_{1} 50$; $\mathrm{Mr}$. Gardiner, University Lecturer in Botany, from $£ 50$ to £ioo.

The Special Board for Biology and Geology, recommend the appointment of an additional University lecturer on botany, at a stipend of $£$ IOO per annum, after considering a strong appeal for increased teaching power, from the professor and lecturers in the subject. No teacher had practically been added since the departure of Prof. Vines for Oxford, and the regretted death of Mr. Vaizey.

Mr. W. Bateson, the Balfour Student, will give a course of lectures during Lent term, on the study of variation - a distinct and attractive novelty in the biological courses.

\section{SCIENTIFIC SERIALS.}

American Jonmal of Science, November.-This number opens with an interesting address by $\mathrm{Mr}$. R. S. Woodward at the last meeting of the American Association, on the mathematical theories of the earth, in which emphasis is laid on the incompleteness of those hitherto advanced. - From a simple investigation, Mr. R. Hooke concludes that for planetary bodies assumed to have the same surface density (i.e. those in which solidification has taken place), the increase of the difference between the mean and surface density is proportional to the increase of the diameter. He tests this by computation of the mean densities of the inner planets from their assigned diameters, and further confirmation is derived from the case of Jupiter's satellites. He also applies the law to computing the ultimate diameters and mean densities (i.e. after solidification) of the sun and outer planets. - Regarding Tschermak's theory of the mica group as inadequate, $\mathrm{Mr}$. F. W. Clarke offers the view that all the micas, vermiculites, chlorites, margarite, and the clintonite group, may be simply represented as isomorphous mixtures, every constituent being a substitution derivative of normal aluminium poly- or ortho-silicate-Mr. E. O. Hovey studies the low trap ridges (some six lines of them) of the East Haven-Branford region in Connecticut; he considers all the trap intrusive, and the western dikes, at least, of later origin than the tilting of the sandstone.-Mr. C. Lea contends that subchloride, and not oxychloride, is the product of the action of light on silver chloride. - There are also papers on an improved standard Clark cell with low temperature coefficient, by Mr. H. S. Carhart; on pseudomiorphs of native copper after azurite, from Grant County, New Mexico, by Mr. W. S. Yeates; and on the relation of volume, pressure, and temperature, in case of liquids, by Mr. C. Barus.

THE American Meteorological Fournal for October contains :A reprint of Prof. C. Abbe's paper on the determination of the amount of rainfall, read before the recent meeting of the British Association; the object of the paper is to determine the possible errors arising from the different shapes of the rain-gauges, and their height above the sea-level and the ground, \&c.-Tornado statistics, by Lieut. Finley : (a) for the State of Louisiana, for the thirty-seven years $1852-88$, - the total number of storms was only thirty, the month of greatest frequency being April ; $(b)$ for Texas, for the thirty years $1850-88$, - the total number of storms was ninety-six, the month of greatest frequency being June.-Distribution of wind velocities in the United States, by Dr. F. Waldo. In the Eastern States there is a principal maxinum and minimum in March and August respectively, with a secondary maximum in autumn, and a winter maximum. The same regularity which exists in the Eastern States does not occur in the other districts, but the region of the Lower Lakes has a little more wind in winter and a little less in summer than the region of the Upper Lakes. He also investigates the secular variation at selected stations, and finds that a period of about nine years is not improbable.-An analysis of a paper, by Dr. H. B. Baker, Secretary of the Michigan Board of Health, on the connection of intermittent fever with atmo pheric temperature. For some years that Board has made a special feature of the collection of vital statistics, and publishes valuable reports on sanitary matters in general.

THE Botanical Gazette continues to publish valuable original contributions to botanical science, especially in the department of cryptogamy. The August number contains the first of a series of Prof. Farlow's notes on Fungi, and the September number an illustrated paper on the Uredo-stage of Gymnosporangizm, by Mr. H. M. Richards. - Mr. H. L. Russell also contributes observations on the temperature of trees, illustrated by a diagram; his general conclusion being that the direct absorption of heat is the main cause of the higher temperature of trees, and that it is largely dependent on the character of the bark.

A LARGE proportion of the Fournal of Botany for August, September, and October, is occupied by the conclusion of $\mathrm{Mr}$. G. Murray's Catalogue of the marine Algx of the West Indian region, and the continuation of Messrs. Britten and Boulger's Biographical Index of British and Irish botanists.-Mr. W. West's paper on the fresh water Algæ of North Yorkshire is a valuable contribution to a department of botany in which there are but few workers; it is illustrated by a good plate, and contains descriptions of several new species. - Mr. W. H. Beeby contributes a useful account of some of the difficult and critical British forms of $V^{i} o^{\prime} a$. - There are other papers of interest, especially to students of British botany.

The number of the Nuovo Giornale Botanico Italiano of October is entirely occupied by papers read at the meetings of the Italian Botanical Society. They are chiefly devoted to records of local floras, and to descriptions of remarkable teratological forms. - Signor U. Martelli contributes a note on the injury inflicted on the peach by Taphrina deformans.

Bulletin de la Société Impériale des Naturainstes de Moscou, 1889, No. I.-On the origin of the shooting-stars, by Th. Bredichin (in French), being an application of the author's theory of the comes anomales to the origin of shooting-stars. The paper will be continued by another on the origin of periodical comets.-On the Jurassic and Cretaceous deposits in Russia; Part $\mathbf{I}$, on the Upper Jurassic and Lower Cretaceous deposits in Russia and Great Britain, by Prof. A. Pavloff (in French, with three plates). The author's conclusions are to the effect that the Upper Jurassic deposits of Russia are so intimately connected with those of England that a common classification could easily be established. Several fossil species are described and figured on plates, three of them being new (Olcosteptranus blaki, $O$. szuindonensis, and $O$. stcnomphalus). - Zoological exploration in the Transcaspian region, by N. Zaroudnoi (in French), being notes of travel, full of interesting information about the nature and fauna of the country.-On a natural way of penetration of superficial water into the depths of the earth, by Stanislas Meunier (in French).-On the Sparganice of Russia, by K. F. Meinshausen (in German). Ten species are described, two of them (Sp. ratis and Sp. septentrionale) being new. 